\title{
Internalization of Titanium Dioxide Nanoparticles Is Cytotoxic for H9c2 Rat Cardiomyoblasts
}

\author{
Elizabeth Huerta-García ${ }^{1}$, Iván Zepeda-Quiroz ${ }^{1}$, Helen Sánchez-Barrera ${ }^{1}$, Zaira Colín-Val ${ }^{1}$, \\ Ernesto Alfaro-Moreno ${ }^{2}$, María del Pilar Ramos-Godinez ${ }^{3}$ and Rebeca López-Marure ${ }^{1, *}$ (iD \\ 1 Departamento de Fisiología (Biología Celular), Instituto Nacional de Cardiología "Ignacio Chávez", \\ Juan Badiano No. 1, Colonia Sección XVI, Tlalpan, C.P. 14080, Ciudad de México, Mexico; \\ marlon_32001@yahoo.com.mx (E.H.-G.); poke_621@hotmail.com (I.Z.-Q.); \\ helenisimasab@gmail.com (H.S.-B.); zaira.cv.10@gmail.com (Z.C.-V.) \\ 2 Swetox, Karolinska Institutet, Unit of Toxicology Sciences, Forskargatan 20, SE-151 36 Södertälje, Sweden; \\ ernesto.alfaro-moreno@swetox.se \\ 3 Departamento de Microscopía Electrónica, Instituto Nacional de Cancerología, Av. San Fernando No. 22, \\ Colonia Sección XVI, Tlalpan, C.P. 14080 Ciudad de México, Mexico; pilyrg@gmail.com \\ * Correspondence: rlmarure@yahoo.com.mx; Tel.: +52-55-55732911 (ext. 25401)
}

Received: 29 June 2018; Accepted: 1 August 2018; Published: 6 August 2018

\begin{abstract}
Titanium dioxide nanoparticles $\left(\mathrm{TiO}_{2} \mathrm{NPs}\right)$ are widely used in industry and daily life. $\mathrm{TiO}_{2}$ NPs can penetrate into the body, translocate from the lungs into the circulation and come into contact with cardiac cells. In this work, we evaluated the toxicity of $\mathrm{TiO}_{2} \mathrm{NPs}$ on $\mathrm{H} 9 \mathrm{c} 2$ rat cardiomyoblasts. Internalization of $\mathrm{TiO}_{2} \mathrm{NPs}$ and their effect on cell proliferation, viability, oxidative stress and cell death were assessed, as well as cell cycle alterations. Cellular uptake of $\mathrm{TiO}_{2} \mathrm{NPs}$ reduced metabolic activity and cell proliferation and increased oxidative stress by 19 -fold measured as $\mathrm{H}_{2}$ DCFDA oxidation. $\mathrm{TiO}_{2} \mathrm{NPs}$ disrupted the plasmatic membrane integrity and decreased the mitochondrial membrane potential. These cytotoxic effects were related with changes in the distribution of cell cycle phases resulting in necrotic death and autophagy. These findings suggest that $\mathrm{TiO}_{2} \mathrm{NPs}_{\text {exposure }}$ represents a potential health risk, particularly in the development of cardiovascular diseases via oxidative stress and cell death.
\end{abstract}

Keywords: titanium dioxide nanoparticles; cardiomyoblasts; internalization; oxidative stress; necrosis; autophagy

\section{Introduction}

Titanium dioxide nanoparticles $\left(\mathrm{TiO}_{2} \mathrm{NPs}\right)$ are widely used in foods, medicines, and cosmetics [1]. Human exposure occurs either by oral, dermal or inhalation routes [2]. Although initially considered safe and inert, $\mathrm{TiO}_{2}$ NPs may actually be harmful for human health. For example, mice exposed to $\mathrm{TiO}_{2}$ NPs developed strong pulmonary inflammation, acute phase responses and cytokine release into circulation [3]. In mice instilled intratracheally with low $(18 \mu \mathrm{g})$ and high $(162 \mu \mathrm{g}) \mathrm{TiO}_{2} \mathrm{NPs}$ doses, these nanoparticles were accumulated in heart and liver and translocated into circulation $24 \mathrm{~h}$ after exposure [4]. $\mathrm{TiO}_{2} \mathrm{NPs}$ activated the complement cascade and inflammatory processes in the heart, and triggered early innate immune responses in blood mediated by the complement factor 3 .

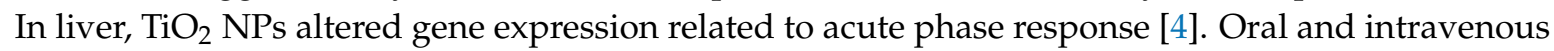
administrations of various $\mathrm{TiO}_{2}$ NPs resulted in accumulation in many organs including liver, lung and heart, regardless of particle size, crystalline form or hydrophobicity [5]. Furthermore, abdominal injection of $\mathrm{TiO}_{2} \mathrm{NPs}$ in mice caused titanium accumulation in several organs, seriously damaging the liver, kidneys and heart and altering blood sugar and lipids [6]. Taken together, these results suggest that $\mathrm{TiO}_{2} \mathrm{NPs}$ can accumulate in different organs producing tissue damage and inflammation. 
Despite $\mathrm{TiO}_{2}$ NPs have been described as an inert material [7], several studies have shown the opposite. In the cardiovascular system, several experiments in vivo have shown myocardial damage, oxidative stress, inflammation and atherosclerosis in mice exposed to $\mathrm{TiO}_{2} \mathrm{NPs}_{\text {[6] }}$. Daily gastrointestinal administration of $\mathrm{TiO}_{2} \mathrm{NPs}$ at $0,2,10,50 \mathrm{mg} / \mathrm{kg}$ in rats for up to three months resulted in cardiac dysfunction and inflammatory response [7]. Intragastric feeding of mice with $\mathrm{TiO}_{2} \mathrm{NPs}$ for nine consecutive months resulted in their accumulation in the heart causing inflammation, apoptosis and cardiac dysfunction [8].

Other studies have shown a strong increase of reactive oxygen species (ROS). Sheng and collaborators [9] administered different doses $\left(2.5,5,10 \mathrm{mg} / \mathrm{kg}\right.$ body weight) of $\mathrm{TiO}_{2} \mathrm{NPs}_{\text {for a }}$ long-term exposure (90 days) inducing oxidative stress and antioxidant system attenuation in mice heart. $\mathrm{TiO}_{2} \mathrm{NPs}$ accumulated in the heart causing sparse cardiac muscle fibers, inflammatory response, cell necrosis, and cardiac biochemical dysfunction. There was an increase of superoxide radicals, hydrogen peroxide, malondialdehyde, carbonyl and $8-\mathrm{OHdG}$, as well as degradation products of proteins, lipids and DNA oxidation [9]. Overall, cell toxicity induced by nanoparticles has been associated to induction of oxidative stress. One study showed that macrophage-like THP-1 and HPMEC-ST1.6R microvascular cells exposed to $\mathrm{TiO}_{2}$ NPs were sensitive to endogenous redox changes and apoptosis [10,11]. A549 cells incubated with $\mathrm{TiO}_{2} \mathrm{NPs}$ (Anatase $22.1 \mathrm{~nm}$ ) for $24 \mathrm{~h}$ showed reduced cell viability and increased lactate dehydrogenase activity in a concentration-dependent manner, indicating cell membrane damage [12]. Also murine microglial cells (BV-2) treated at different concentrations of $\mathrm{TiO}_{2} \mathrm{NPs}\left(0.1\right.$ to $200 \mu \mathrm{g} / \mathrm{mL}$ ) showed a slight inhibition of cell growth. High $\mathrm{TiO}_{2} \mathrm{NPs}$ concentrations enhanced permeability of cytoplasmic membrane to propidium iodide (PI), associated with loss of mitochondrial membrane potential $(\Delta \Psi \mathrm{m})$ and overproduction of superoxide anions [13]. In primary rat cortical astrocytes and human lung fibroblast cells (WI-38), $\mathrm{TiO}_{2} \mathrm{NPs}_{\text {induced } \mathrm{ROS}}$ generation and reduced $\Delta \Psi \mathrm{m}$ [14]. Moreover, food grade $\mathrm{TiO}_{2} \mathrm{NPs}_{\text {s }}$ promoted intracellular oxidative stress in WI-38 cells, altering cell cycle progression (G2/M > S > G0/G1) [15].

Many studies have described negative effects of $\mathrm{TiO}_{2} \mathrm{NPs}$ in various systems and cell types $[2,11]$. In the cardiovascular system, these nanoparticles induce tissue damage and inflammatory responses; however, the underlying mechanisms are not well understood. Therefore, in order to assess the impact of $\mathrm{TiO}_{2} \mathrm{NPs}$ on cardiac cells we evaluated their cellular uptake in $\mathrm{H} 9 \mathrm{c} 2$ rat cardiomyoblasts and the mechanisms associated with their nanotoxicity.

Since $\mathrm{TiO}_{2} \mathrm{NPs}$ can translocate into the systemic circulation and the heart [4], we hypothesized that these nanoparticles could induce damage to cardiac cells. To test this hypothesis, we exposed H9c2 cells to $\mathrm{TiO}_{2} \mathrm{NPs}$ and examined their effects on cell cycle phases, mitochondrial function, oxidative stress, cell death and autophagy.

\section{Results}

\subsection{Internalization of $\mathrm{TiO}_{2} \mathrm{NPS}$}

Due to their small size, nanoparticles uptake can occur in cardiac cells. In order to corroborate this, $\mathrm{H} 9 \mathrm{c} 2$ cells were exposed to $5 \mu \mathrm{g} / \mathrm{cm}^{2} \mathrm{TiO}_{2} \mathrm{NPs}$ for $24 \mathrm{~h}$ and were then analyzed by transmission electron microscopy (TEM). Numerous nanoparticle aggregates with size $<500 \mathrm{~nm}$ were observed inside cells (Figure 1B); however, large aggregates $>2 \mu \mathrm{M}$ were also present (Figure 1C,D). Internalized $\mathrm{TiO}_{2} \mathrm{NPs}$ were localized in the cytoplasm but solid core NPs were not observed inside cell organelles. 

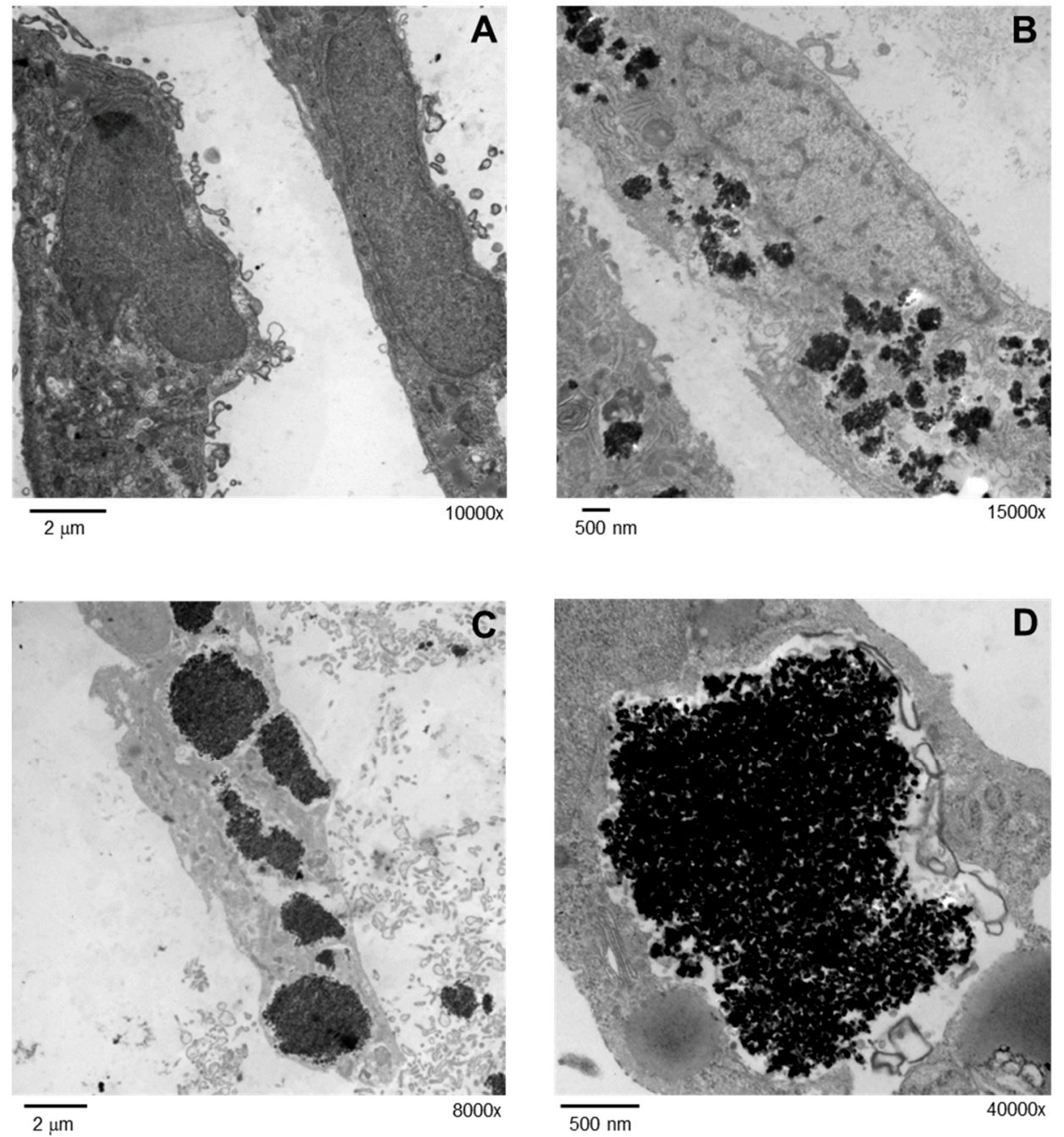

Figure 1. Internalization of $\mathrm{TiO}_{2} \mathrm{NPs}$ was evaluated by TEM. Cells were treated with $5 \mu \mathrm{g} / \mathrm{cm}^{2} \mathrm{TiO}_{2}$ NPs for $24 \mathrm{~h}$ and analyzed in a JEOL 10-10 microscope and an AMT Camera System. TEM micrographs of non-exposed cells at a direct magnification of $10,000 \times(\mathbf{A})$ and treated cells a magnification of $15,000 \times(\mathbf{B}), 8000 \times(\mathbf{C})$ and $40,000 \times(\mathbf{D})$ are shown.

\section{2. $\mathrm{TiO}_{2} \mathrm{NPs}$ Inhibited Proliferation and Decreased Metabolic Activity}

Large $\mathrm{TiO}_{2}$ NPs aggregates observed inside cells could induce cytostatic/cytotoxic effects, therefore we evaluated their impact on cell proliferation and viability. To measure proliferation, $\mathrm{H} 9 \mathrm{c} 2$ cells were exposed to different $\mathrm{TiO}_{2}$ NPs concentrations for $72 \mathrm{~h}$ and were stained with crystal violet. Results showed that high NPs concentrations (20 and $40 \mu \mathrm{g} / \mathrm{cm}^{2}$ ) decreased cell proliferation in about $30 \%$ ( $p<0.05$ versus control cells) (Figure 2A). To evaluate viability, a MTT assay was performed. The metabolic activity was measured by MTT reduction to purple formazan by mitochondrial dehydrogenases in living cells. $\mathrm{TiO}_{2} \mathrm{NPs}$ from $5 \mu \mathrm{g} / \mathrm{cm}^{2}$ decreased cell metabolic activity by $30 \%$, and the maximum effect was achieved at $40 \mu \mathrm{g} / \mathrm{cm}^{2}$ with $60 \%$ inhibition, compared to control cells (Figure 2B). The half maximal inhibitory concentration ( $\left.\mathrm{IC}_{50}\right)$ was $20 \mu \mathrm{g} / \mathrm{cm}^{2}(100 \mu \mathrm{g} / \mathrm{mL})$; therefore, further experiments in $\mathrm{H} 9 \mathrm{c} 2$ cells were performed at this concentration. 
A

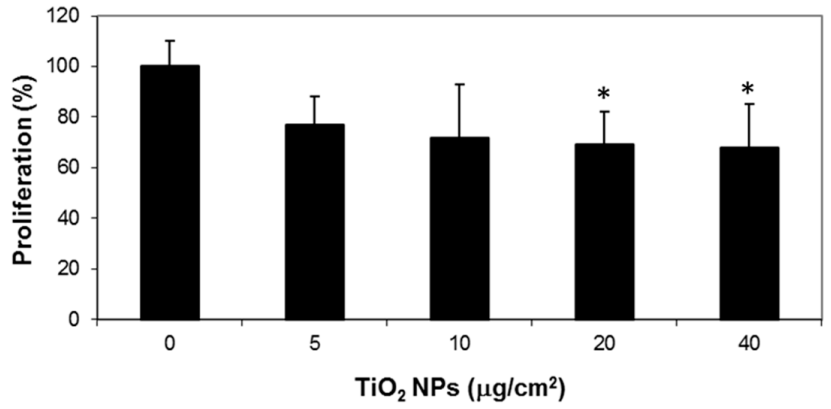

B

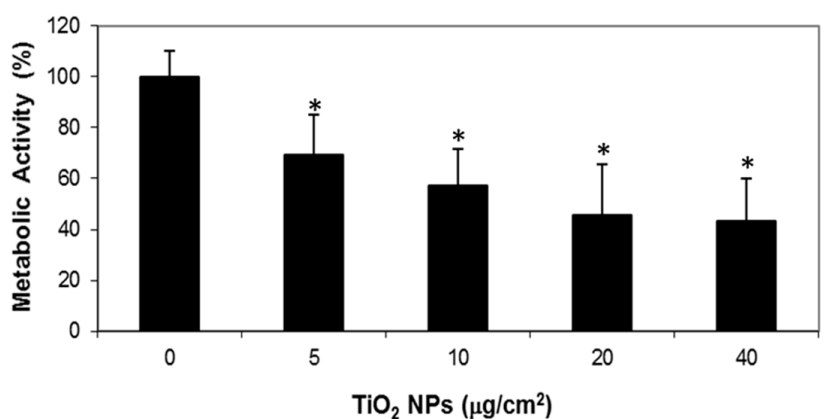

Figure 2. $\mathrm{TiO}_{2} \mathrm{NPs}$ treatment inhibited cell proliferation and decreased metabolic activity. H9c2 cells were treated with different $\mathrm{TiO}_{2} \mathrm{NPs}$ concentrations $\left(5,10,20,40 \mu \mathrm{g} / \mathrm{cm}^{2}\right)$ for $48 \mathrm{~h}$. Cell proliferation was evaluated by crystal violet staining and viability by MTT reduction. Results were expressed as mean \pm standard deviation (SD) of three independent experiments $(n=15)$. ${ }^{*}$ Significant difference between control (untreated) and treated cells $(p<0.05)$.

\section{3. $\mathrm{TiO}_{2} \mathrm{NPs}$ Changed Cellular Redox State}

$\mathrm{TiO}_{2}$ NPs diminished cell viability and this cytotoxic effect is generally associated with oxidative stress. Therefore, we measured cellular redox state and ROS production by $2^{\prime}, 7^{\prime}$-dichlorodihydrofluorescein diacetate $\left(\mathrm{H}_{2}\right.$ DCFDA) oxidation. Results showed that $\mathrm{TiO}_{2}$ NPs strongly increased the fluorescence intensity in direct proportion to $\mathrm{H}_{2} \mathrm{DCFDA}$ oxidation. This increment was observed at all evaluated times; however, the highest effect was obtained at day one of treatment with a 17 -fold increase $(p>0.05)$ vs. control cells (Figure 3).

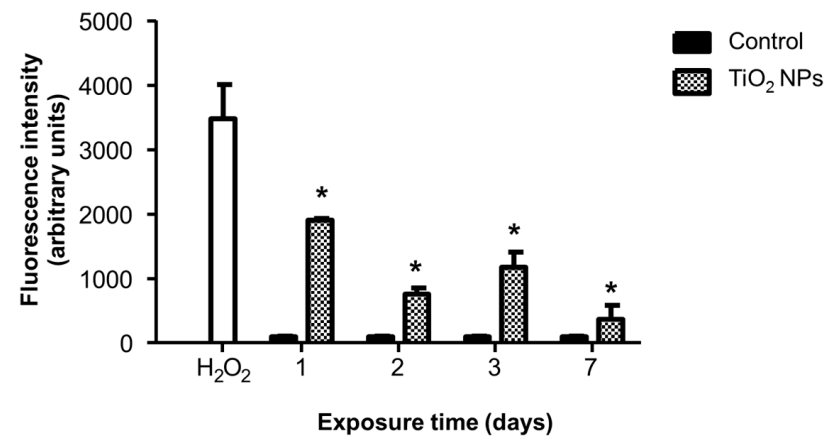

Figure 3. $\mathrm{TiO}_{2} \mathrm{NPs}$ treatment changed cellular redox state. $\mathrm{H} 9 \mathrm{c} 2$ cells were treated with $\mathrm{TiO}_{2} \mathrm{NPs}$ $\left(20 \mu \mathrm{g} / \mathrm{cm}^{2}\right)$ alone for $1,2,3$, and 7 days and cellular redox state was evaluated by $\mathrm{H}_{2}$ DCFDA oxidation. Cells treated with $\mathrm{H}_{2} \mathrm{O}_{2}(500 \mu \mathrm{M})$ for 1 day were used as positive controls. Results were expressed as fluorescence intensity in arbitrary units and as mean \pm standard deviation (SD) of three independent experiments $(n=15)$. ${ }^{*}$ Significant difference between control (untreated) and treated cells $(p<0.05)$. 


\section{4. $\mathrm{TiO}_{2} \mathrm{NPs}$ Decreased the Mitochondrial Membrane Potential}

Oxidative stress was measured by changes in the $\Delta \Psi \mathrm{m}$ with rhodamine 123 (Rh123). This molecule is cell membrane permeable and localizes in the mitochondria of viable cells, but when the $\Delta \Psi \mathrm{m}$ is altered, $\mathrm{Rh} 123$ is released and the fluorescence intensity decreases. $\mathrm{TiO}_{2} \mathrm{NPs}$ decreased the fluorescence by $50 \%$ with a significant statistical difference from $48 \mathrm{~h}$ of treatment, indicating alterations in the $\Delta \Psi \mathrm{m}$ (Figure 4).

A $24 \mathrm{~h}$

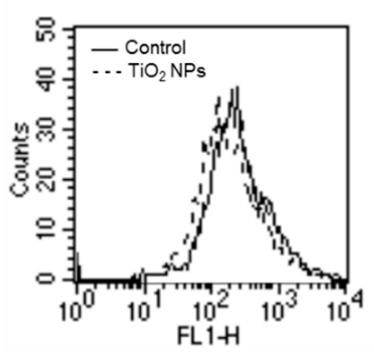

$48 \mathrm{~h}$

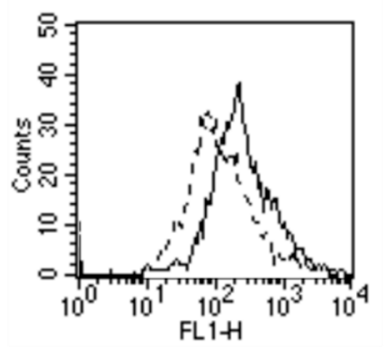

$72 \mathrm{~h}$

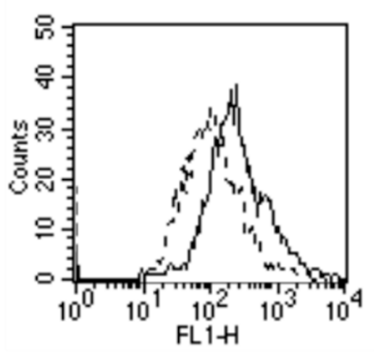

B

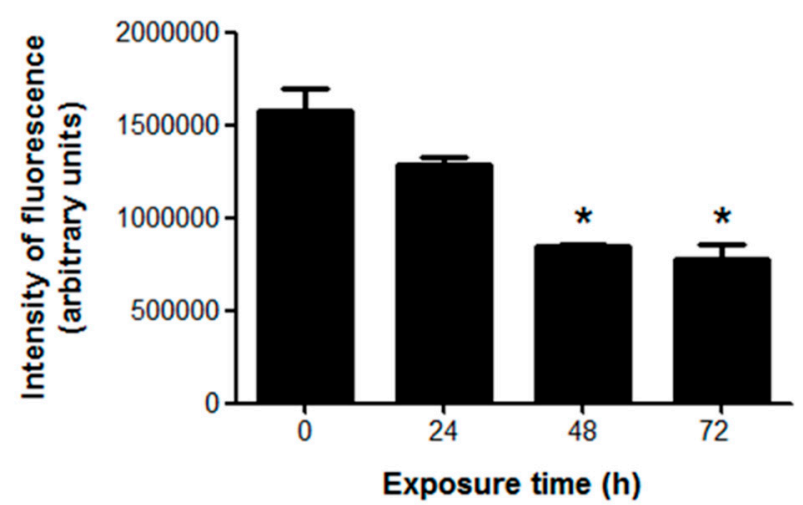

Figure 4. $\mathrm{TiO}_{2} \mathrm{NPs}$ decreased $\Delta \Psi \mathrm{m}$ in $\mathrm{H} 9 \mathrm{c} 2$ cells treated with $20 \mu \mathrm{g} / \mathrm{cm}^{2} \mathrm{TiO}_{2} \mathrm{NPs}$ for 24,48 , and $72 \mathrm{~h} . \Delta \Psi \mathrm{m}$ changes were measured by the fluorescent dye Rh123 in a flow cytometer. (A) Histograms of a representative experiment performed independently. (B) Densitometric analysis expressed as fluorescence intensity (arbitrary units). Data are presented as mean \pm standard deviation (SD) of three independent experiments $(n=3)$. * Significant difference between control (untreated) and treated cells $(p<0.05)$.

\section{5. $\mathrm{TiO}_{2} \mathrm{NPs}$ Altered Cell Cycle Phases}

To determine whether the effect of $\mathrm{TiO}_{2} \mathrm{NPs}$ on cell proliferation and viability was associated with cell cycle alterations, $\mathrm{H} 9 \mathrm{c} 2$ cells were exposed to $20 \mu \mathrm{g} / \mathrm{cm}^{2} \mathrm{TiO}_{2} \mathrm{NPs}$ for 24,48 and $72 \mathrm{~h}$ and the cell cycle phases were evaluated. The number of cells in the G1 phase decreased by $22 \%$ after $48 \mathrm{~h}$ of treatment and reached $34 \%$ at $72 \mathrm{~h}$ compared with control cells. No significant changes were observed in the $S$ and G2/M phases in the same periods. The percentages of sub G1 cells significantly increased in a time-dependent manner, and peaked at $72 \mathrm{~h}$ with $39.9 \%$. These results indicate that NPs caused important changes in the distribution of cell cycle phases after $48 \mathrm{~h}$ of exposure (Figure 5). 
A
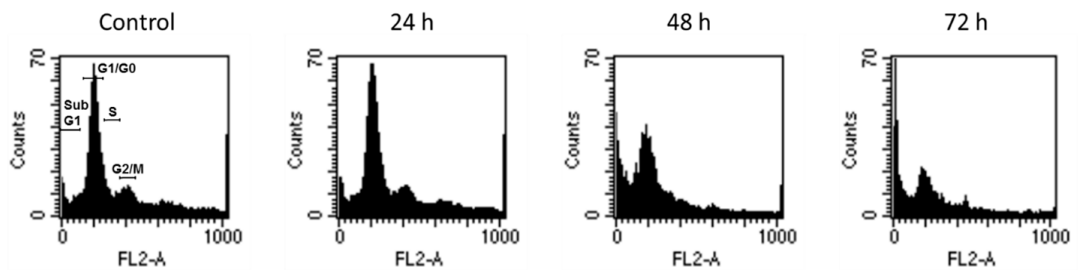

B

\begin{tabular}{lcccc}
\hline Treatment & G0/G1 & S & G2/M & Sub-G1 \\
\hline Control & $58.7 \pm 4.2$ & $14.3 \pm 1.3$ & $12.5 \pm 0.4$ & $14.5 \pm 3.3$ \\
$\mathrm{TiO}_{2}$ NPs 24 h & $53.3 \pm 5.1$ & $15.6 \pm 8.1$ & $10.7 \pm 4.8$ & $20.4 \pm 8.4$ \\
$\mathrm{TiO}_{2}$ NPs 48 h & $36.2 \pm 14 *$ & $14.7 \pm 3.8$ & $9.1 \pm 2.9$ & $40 \pm 7.1 *$ \\
$\mathrm{TiO}_{2}$ NPs $72 \mathrm{~h}$ & $24.8 \pm 2.6 *$ & $12.7 \pm 5.3$ & $8.1 \pm 2.3$ & $54.4 \pm 19.5 *$ \\
\hline
\end{tabular}

Figure 5. Effect of $\mathrm{TiO}_{2} \mathrm{NPs}$ on cell cycle. H9c2 cells were treated with $20 \mu \mathrm{g} / \mathrm{cm}^{2} \mathrm{TiO}_{2} \mathrm{NPs}$ for 24, 48 , and $72 \mathrm{~h}$ and cell cycle was analyzed by quantitation of DNA content through flow cytometry. Histograms (A) and table (B) show the percentage of cell populations in each phase. In (B), data were analyzed by the CellQuest Pro software (Becton Dickinson) and expressed as mean \pm standard deviation (SD) of three independent experiments $(n=3)$. * Significant difference between control (untreated) and treated cells $(p<0.05)$.

\section{6. $\mathrm{TiO}_{2} \mathrm{NPs}$ Induced Necrotic Death and Autophagy}

Since $\mathrm{TiO}_{2}$ NPs induced a significant increase in sub-G1 peak, we characterized the type of cell death. No significant change in apoptosis was observed with $\mathrm{TiO}_{2} \mathrm{NPs}$ at any time; however, $\mathrm{TiO}_{2} \mathrm{NPs}$ produced a slight but significant $20 \%$ increase in necrotic cell death after $24 \mathrm{~h}$ of treatment (Figure 6). This was consistent with higher LDH release $(30 \%)(p<0.05)$ at 24 and $48 \mathrm{~h}$ (Figure 7).

A
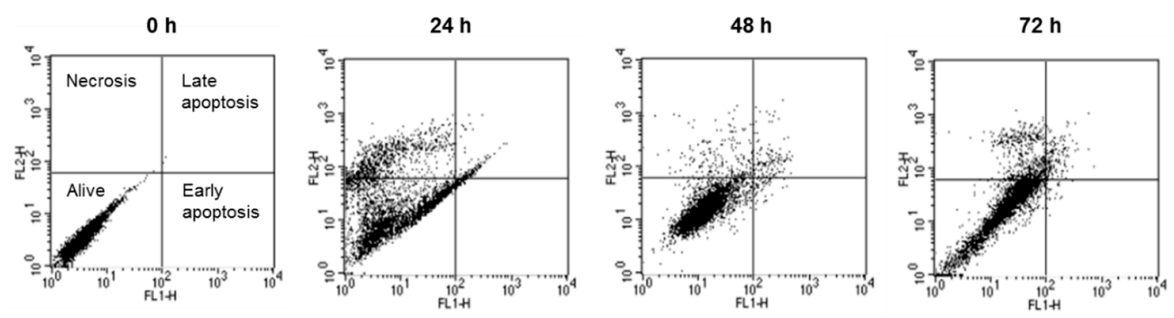

B

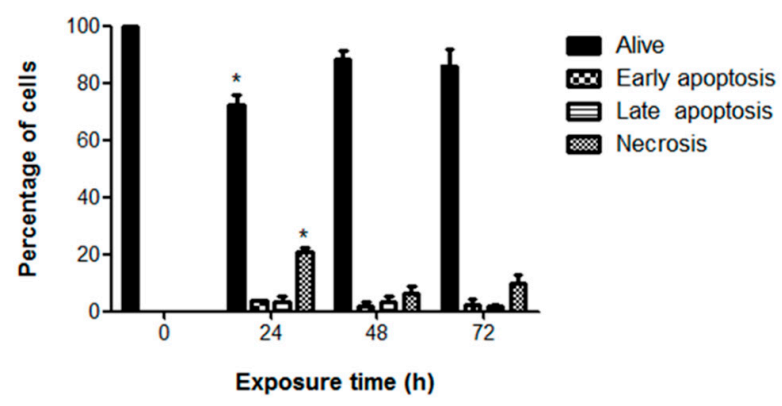

Figure 6. $\mathrm{TiO}_{2} \mathrm{NPs}$ induced necrotic death. $\mathrm{H} 9 \mathrm{c} 2$ cells were treated with $20 \mu \mathrm{g} / \mathrm{cm}^{2} \mathrm{TiO}_{2} \mathrm{NPs}_{\text {for }} 24$, 48 , and $72 \mathrm{~h}$, then apoptotic and necrotic death was measured by annexin- $\mathrm{V}$ and propidium iodide staining. Dot blots show resolution of live, apoptotic and necrotic populations (A) and the bar chart show the percentages $(\mathbf{B})$ as mean \pm standard deviation (SD) of three independent experiments $(n=3)$. * Significant difference between control (untreated) and treated cells $(p<0.05)$. 


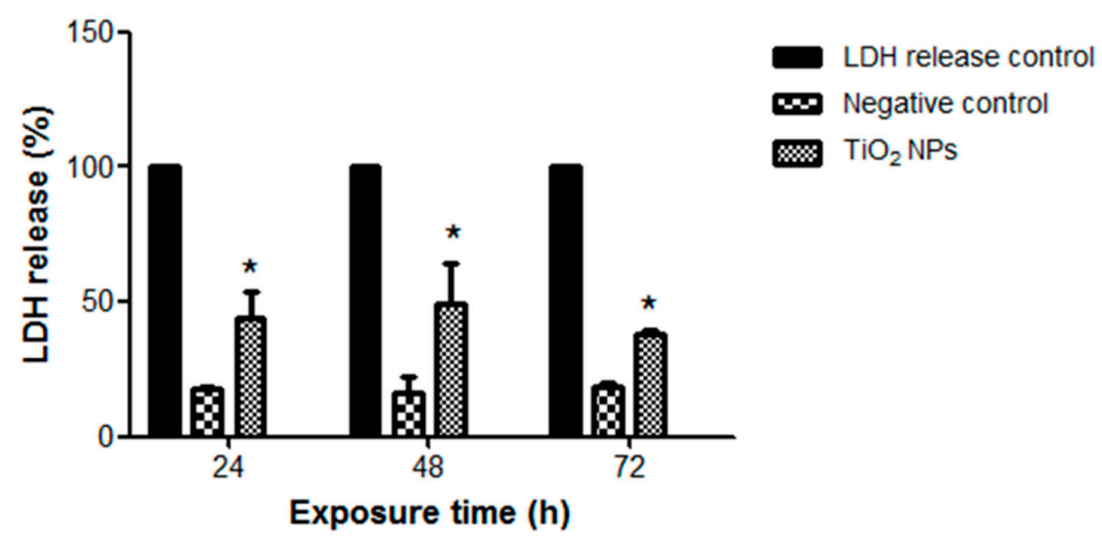

Figure 7. $\mathrm{TiO}_{2} \mathrm{NPs}$ induced LDH release. $\mathrm{H} 9 \mathrm{c} 2$ cells were treated with $20 \mu \mathrm{g} / \mathrm{cm}^{2} \mathrm{TiO}_{2} \mathrm{NPs}$ for 24, 48 , and $72 \mathrm{~h}$ and then an LDH-based cytotoxicity assay was performed. Results are presented as mean \pm standard deviation (SD) of three independent experiments $(n=3)$. ${ }^{*}$ Significant difference between negative control (untreated) and treated cells $(p<0.05)$.

$\mathrm{TiO}_{2} \mathrm{NPs}$ also induced strong morphological changes related to increased numbers of cell vacuoles (data not shown). Since autophagy is a self-degradative process and a survival mechanism involving generation of vacuoles [16], autophagic vesicles were detected using a novel and selective green fluorescent dye. $\mathrm{TiO}_{2}$ NPs induced a nine-fold increase of fluorescence after $24 \mathrm{~h}$ of treatment, indicating the formation of autophagic vacuoles (Figure 8).

A

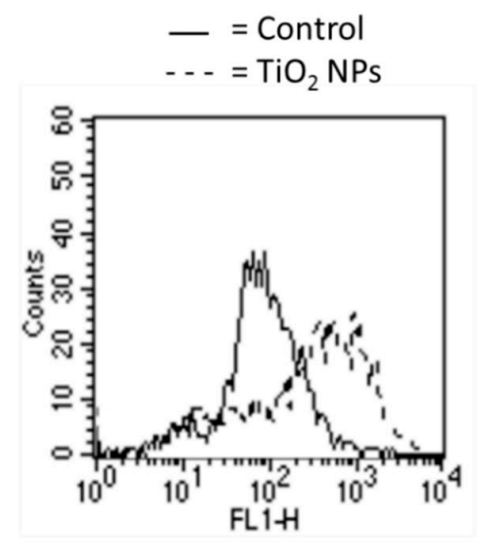

C

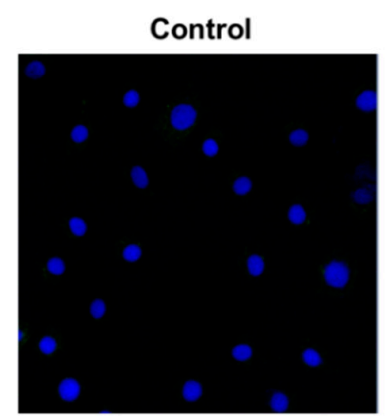

B
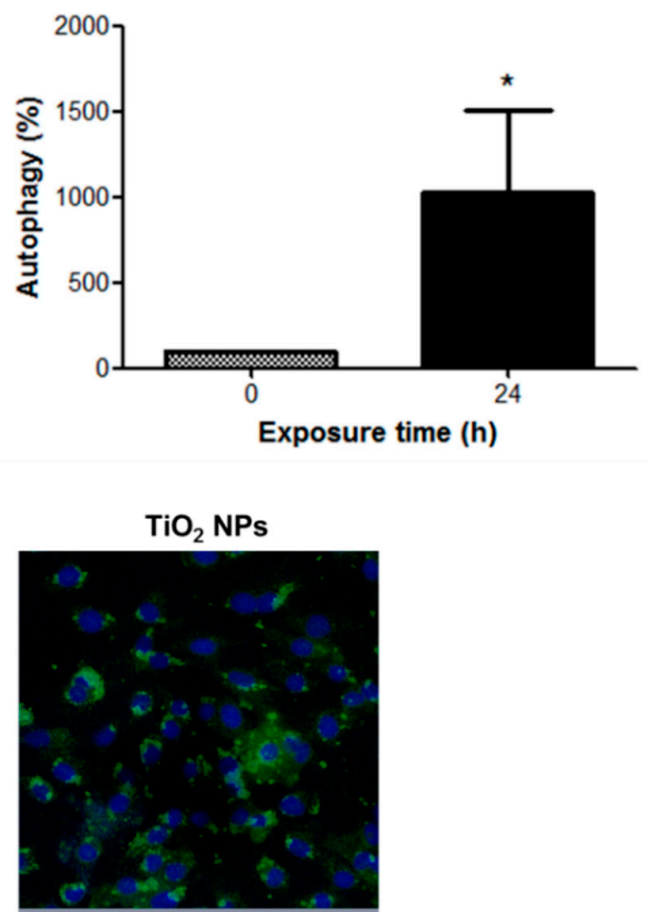

Figure 8. $\mathrm{TiO}_{2} \mathrm{NPs}$ induced autophagy. $\mathrm{H} 9 \mathrm{c} 2$ cells were treated with $20 \mu \mathrm{g} / \mathrm{cm}^{2} \mathrm{TiO}_{2} \mathrm{NPs}$ for $24 \mathrm{~h}$ and autophagy was evaluated through a detection kit by flow cytometry (A,B) and confocal microscopy (C). In (B), results are presented as mean \pm standard deviation (SD) of three independent experiments $(n=3)$. * Significant difference between untreated cells $(0)$ and $\mathrm{TiO}_{2}$ NPs-treated cells $(p<0.05)$. In $(\mathbf{C})$, nuclear stain with DAPI and green detection reagent (autophagy) are showed. 


\section{Discussion}

There is evidence that $\mathrm{TiO}_{2} \mathrm{NPs}$ can translocate to the heart via systemic circulation [4]. In this work we evaluated whether $\mathrm{TiO}_{2}$ NPs could have adverse effects on cardiomyocytes, measured through cell viability, oxidative stress, $\Delta \Psi \mathrm{m}$, cell cycle and cell death.

$\mathrm{TiO}_{2}$ NPs decreased cell proliferation and induced a strong cytotoxic effect on H9c2 cells, associated with increased oxidative stress and alterations of $\Delta \Psi \mathrm{m}$. Important changes in cell cycle phases were observed in association with necrotic death and autophagy. $\mathrm{TiO}_{2} \mathrm{NPs}$ also disrupted the integrity of cell membrane leading to increased permeability and LDH release (Figure 6).

Despite the fact $\mathrm{TiO}_{2} \mathrm{NPs}$ have been considered as inert and nontoxic, a growing body of evidence suggests quite the opposite. Cytotoxic effects of $\mathrm{TiO}_{2} \mathrm{NPs}$ are generally associated with cell growth inhibition in different cells types [13,17-22]; however, our results are the first evidence of their toxicity in cardiac H9c2 cells. The inhibitory concentration $\mathrm{IC}_{50}$ was $20 \mu \mathrm{g} / \mathrm{cm}^{2}(75 \mu \mathrm{g} / \mathrm{mL})$, consistent with other in vitro studies [23]. Although this concentration of $\mathrm{TiO}_{2} \mathrm{NPs}$ is higher than those of occupational exposure or commercial products, $\mathrm{TiO}_{2} \mathrm{NPs}$ may accumulate by long-term exposure and become toxic. Particles of few nanometers in size can translocate through the air-blood-barrier in approximately $10 \%$ [24]. Considering that $40 \mu \mathrm{g} / \mathrm{cm}^{2}$ of $\mathrm{TiO}_{2} \mathrm{NPs}$ could be present in hot-spots of airways and lungs of exposed humans [25], then approximately $4 \mu \mathrm{g} / \mathrm{cm}^{2}$ could enter into systemic circulation. Once there, particles become highly diluted, but their bioaccumulation in different tissues is not well documented, therefore we hypothesized that these concentrations could be reached over long-term exposures. In a recent study, the biokinetics of $48 \mathrm{~V}$-radiolabeled $\mathrm{TiO}_{2} \mathrm{NPs}_{\text {sas }}$ investigated in rats at retention time points 1, 4, 24h and seven days after oral application of a single dose by intra-esophageal instillation. Their results showed that $0.6 \%$ of the administered dose passed the gastro-intestinal-barrier after one hour and about $0.05 \%$ was still distributed in the body after seven days, indicating the possibility of chronic accumulation of nanoparticles in secondary organs and the skeleton [26].

We observed internalization of $\mathrm{TiO}_{2} \mathrm{NPs}$ by $\mathrm{H} 9 \mathrm{c} 2$ cells and these nanoparticles remained within cells even after cell division. Nanoparticles were accumulated in the cytoplasm but no interactions with organelles were observed (Figure 1). Chronic exposures at low concentrations of $\mathrm{TiO}_{2} \mathrm{NPs}$ in human bronchial epithelium cells (BEAS-2B) showed cellular uptake and cell transformation [27], supporting our observations. Few studies have analyzed the exocytosis of nanoparticles in mammalian cells. Wang et al. [28] showed that $\mathrm{TiO}_{2} \mathrm{NPs}$ were internalized by the neural stem cells after $48 \mathrm{~h}$ incubation, and only $35 \%$ was exocytosed after $24 \mathrm{~h}$.

Nanoparticles interact directly with cells as complexes or aggregates [29]. The real identity and toxicity of $\mathrm{TiO}_{2}$ NPs in biological systems is a function of surface charge, size, solubility, shape, hydrophobicity, dose and crystalline structures [30]. Nanoparticle surface becomes saturated by phospholipids, proteins, DNA, small molecules and inorganic ions. The nanoparticle surface ligand induces protein corona misfolding and therefore indirectly enhances cellular uptake [31].

$\mathrm{TiO}_{2}$ reduction to nanosize increases surface area changing their electronic configuration and reactivity. These modifications also affect cell binding and internalization. The size of $\mathrm{TiO}_{2} \mathrm{NPs}$ aggregates in culture medium containing FBS is reduced, enhancing dispersion [32], facilitating contact with cells and toxicity.

Our results showed that $\mathrm{TiO}_{2} \mathrm{NPs}$ induced oxidative stress in $\mathrm{H} 9 \mathrm{c} 2$ cells evidenced by changes in redox state (increased ROS production). After one day of exposure, $\mathrm{TiO}_{2} \mathrm{NPs}$ induced ROS generation but this declined after two days. A subsequent increase and decrease occurred at three and seven days, respectively. We hypothesize that after two days of treatment, the antioxidant defense system counteracts cell and mitochondrial damage, but after three days, cells lose this capacity. After seven days of exposure, the extent of cell damage is greater, making difficult to evaluate ROS production. $\mathrm{TiO}_{2}$ NPs can produce ROS such as hydroxyl radicals and superoxides in the dark. These oxidize serum proteins to form a protein corona on the nanoparticles surface. This oxidized protein could be responsible for the oxidative stress induced by $\mathrm{TiO}_{2} \mathrm{NPs}$ in $\mathrm{H} 9 \mathrm{c} 2$ cells [33]. In a previous experiment 
performed in acellular conditions using a dithiothreitol (DTT) assay [34], we found the oxidant potential of $\mathrm{TiO}_{2} \mathrm{NPs}$.

Oxidative stress appears to be the underlying mechanism of in vivo genotoxicity of titanium [35]. We previously showed that oxidative stress induced by $\mathrm{TiO}_{2} \mathrm{NPs}$ can upregulate early and late receptors for adhesion molecules on monocytes [36]. Taken together, these data indicate that oxidative stress plays an important role and could be the primary mechanism for $\mathrm{TiO}_{2} \mathrm{NPs}$ toxicity in cardiomyoblasts.

Oxidative stress was related with dissipation of $\Delta \Psi \mathrm{m}$ in $\mathrm{H} 9 \mathrm{c} 2$ cells, indicating mitochondrial dysfunction. Similar results were observed in $\mathrm{H} 9 \mathrm{c} 2$ cells exposed to platinum-coated $\mathrm{TiO}_{2} \mathrm{NPs}\left(\mathrm{Pt}-\mathrm{TiO}_{2}\right.$ NPs) [37]; and in primary astrocytes exposed to different types of $\mathrm{TiO}_{2} \mathrm{NPs}$, altering mitochondrial morphology, ROS generation, and $\Delta \Psi \mathrm{m}$, suggesting mitochondrial damage [14]. Mitochondrial dysfunction leads to ROS overproduction, damage to cellular components and cell death, forming a vicious cycle [38].

Studies in yeast and complex eukaryotes show that fluctuations in oxygen consumption, energy metabolism, and cell redox state are intimately integrated with cell cycle progression [39]. Therefore, we evaluated cell cycle phases in $\mathrm{H} 9 \mathrm{c} 2$ cells exposed to $\mathrm{TiO}_{2} \mathrm{NPs}$. Our results showed that $\mathrm{TiO}_{2} \mathrm{NPs}$ induced changes in the cell cycle. The proportion of G0/G1 phase cells decreased and the percentage of sub-G1 region events increased after 48 and $72 \mathrm{~h}$ of exposure, associated with necrosis and autophagy. Different forms of $\mathrm{TiO}_{2} \mathrm{NPs}$ induced cell cycle arrest in various cells types $[15,40,41]$, in connection with elevated ROS levels $[40,42,43]$, indicating that cytotoxic effects of $\mathrm{TiO}_{2} \mathrm{NPs}$ are related to oxidative stress, cell cycle alterations and cell death.

$\mathrm{H} 9 \mathrm{c} 2$ cells exposed to $\mathrm{TiO}_{2}$ NPs had severe damage resulting in strong autophagy (Figure 8). Autophagy involves lysosomal degradation of cytoplasmic components such as mitochondria and other intra-cellular structures $[44,45]$. Autophagy increases following mitochondrial dysfunction such as generation of low ATP levels; therefore, mitochondria have a key role in autophagy [46]. Autophagy is implicated in tumor suppression through cell cycle arrest, promoting genome and organelle integrity, or through inhibition of necrosis-mediated inflammation [16]. Autophagy has also been linked to pathologic conditions of cardiac remodeling that involve an increase of cardiomyocyte death [47-50]. Autophagy observed in $\mathrm{H} 9 \mathrm{c} 2$ cells may be a consequence of necrosis and inflammation induced by $\mathrm{TiO}_{2} \mathrm{NPs}$ in order to counteract the damage. In the heart autophagy can be either beneficial or harmful, but enhanced autophagy can induce cell death [51].

Some degree of necrosis but not apoptosis was observed in $\mathrm{H} 9 \mathrm{c} 2$ cells exposed to $\mathrm{TiO}_{2} \mathrm{NPs}$. Cardiomyocytes may undergo apoptosis, necrosis and autophagic death [52]. Necrosis and apoptotic cell death depend in part, on ATP levels. In situations where ATP depletion is extreme, apoptosis is inhibited and then necrosis might occur [52]. Necrosis may also result from acidosis and higher calcium concentrations. Nanoparticles possibly induced changes in ATP levels, acidosis or increased intracellular calcium levels resulting in necrotic death of $\mathrm{H} 9 \mathrm{c} 2$ cells.

The mitochondrial intermembrane protein and activator of caspases is released from the intermembrane space following outer membrane rupture. ROS production and mitochondrial alterations induced by $\mathrm{TiO}_{2}$ NPs in $\mathrm{H} 9 \mathrm{c} 2$ cells may promote mitochondrial permeability transition and subsequent cell death. Cellular features of necrosis, apoptosis, and autophagy frequently co-occur after death signals and toxic stress [50]. Further studies are needed to evaluate whether long term exposure of cells to $\mathrm{TiO}_{2} \mathrm{NPs}$ produces autophagic death.

In summary, $\mathrm{TiO}_{2} \mathrm{NPs}$ cause severe damage to cardiomyoblasts cells in vitro through inhibition of proliferation (1), induction of oxidative stress and mitochondrial dysfunction $(2,3)$, autophagy (4), membrane permeability and necrotic death (5) (Figure 9), indicating that occupational and environmental exposures to these NPs, could eventually lead to heart damage and the development of cardiovascular diseases. Taken together, these results suggest that nanoparticles accumulation in cardiomyoblasts, could eventually drive cardiac damage and adverse health effects in the exposed population. 


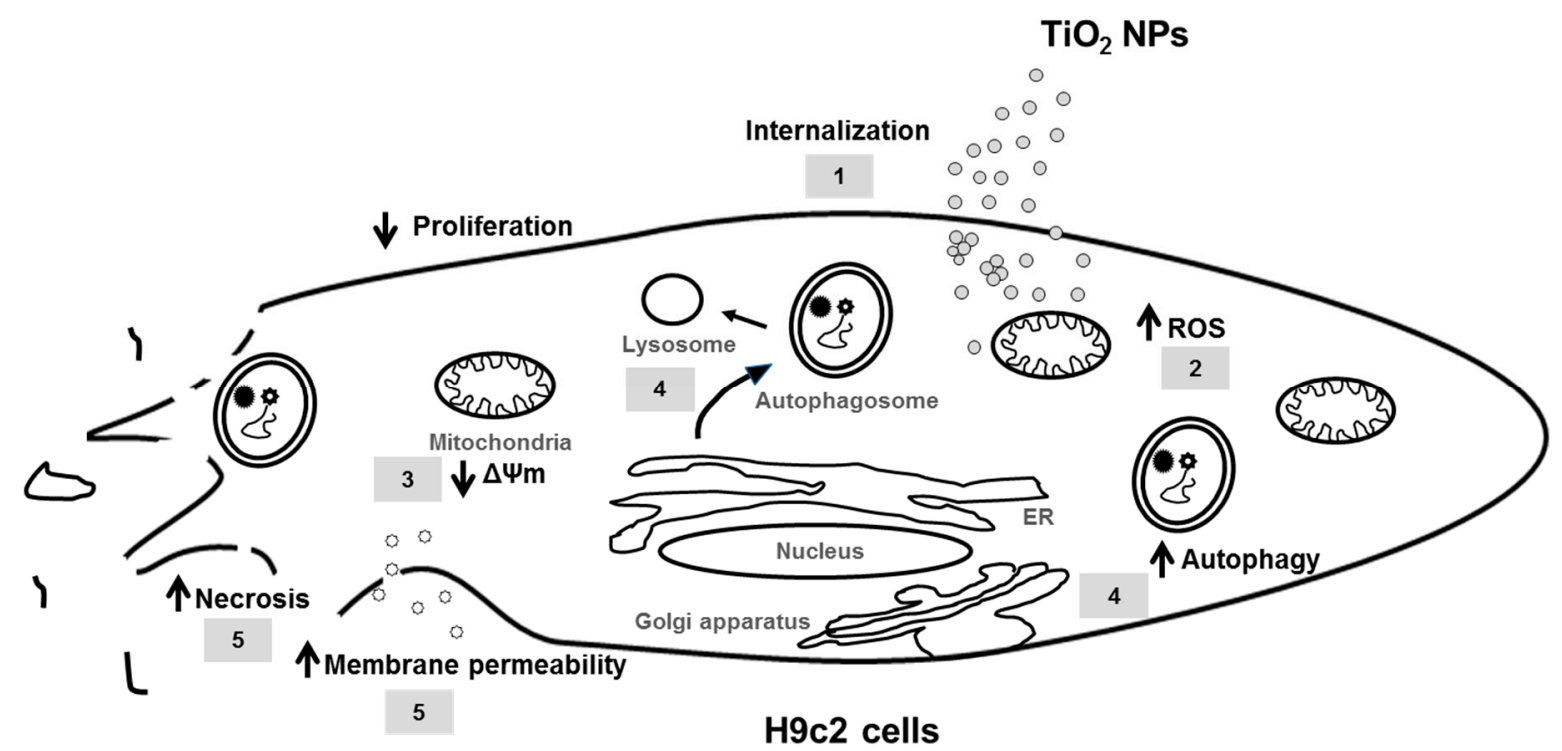

Figure 9. Toxic effects induced by $\mathrm{TiO}_{2} \mathrm{NPs}$ in $\mathrm{H} 9 \mathrm{c} 2$ cells. $\mathrm{TiO}_{2} \mathrm{NPs}$ are internalized into the cytoplasm (1), producing strong oxidative stress and changes in the cellular redox state, increasing ROS production and mitochondrial damage (2), decreasing mitochondrial membrane potential $(\Delta \Psi \mathrm{m})$ (3). High oxidative stress causes strong cell damage, associated with autophagy (4), involving the formation of autophagosomes in the endoplasmic reticulum (ER), these in turn fuse with lysosomes to produce degradation of cytoplasmic components formed during cell damage. Finally, $\mathrm{TiO}_{2} \mathrm{NPs}_{\mathrm{s}}$ increase membrane permeability and induce necrosis (5).

\section{Methods}

\subsection{Materials}

Dulbecco's modified Eagle's medium (DMEM) high glucose, $0.25 \%$ trypsin-EDTA solution, Antibiotic Antimycotic Solution $(100 \times)$, and fetal bovine serum (FBS) were acquired from Gibco BRL (Grand Island, NY, USA). Cell culture consumables were purchased from Corning (Corning, NY, USA). Flow cytometry reagents were provided by Becton-Dickinson Immunocytometry Systems (San Jose, CA, USA). $\mathrm{H}_{2}$ DCFDA was purchased from Molecular Probes, Invitrogen (Carlsbad, CA, USA). CytoTox 96 Non-radioactive cytotoxicity assay was from Promega (Madison, WI, USA). Western blot reagents were from Bio-Rad (Hercules, CA, USA). Autophagy detection kit was purchased from abcam (Cambridge, MA, USA). Anatase $\mathrm{TiO}_{2} \mathrm{NPs} 25 \mathrm{~nm}$ and other chemicals were obtained from Sigma-Aldrich (St. Louis, MO, USA).

\subsection{Culture of Embryonic Rat H9c2 Cardiomyoblast Cells}

$\mathrm{H} 9 \mathrm{c} 2$ rat cardiomyoblasts were used as a model since they mimic the hypertrophic responses of primary rat neonatal cardiomyocytes in vitro [53]. H9c2 cells were purchased from the American Type Culture Collection (CRL-1446, ATCC, Manassas, VA, USA) and cultured with DMEM high glucose added with $10 \%$ fetal bovine serum (FBS) plus an antibiotic-antimycotic solution. Cells were cultured at $37^{\circ} \mathrm{C}$ in a humidified atmosphere of $5 \% \mathrm{CO}_{2}$.

\subsection{Titanium Dioxide Nanoparticles}

$\mathrm{TiO}_{2}$ NPs were previously characterized by our group [54]. $\mathrm{TiO}_{2} \mathrm{NPs}$ have a surface area of $45-50 \mathrm{~m}^{2} / \mathrm{g}$ with average particle size of $19 \mathrm{~nm}$ and $\zeta$-potential of $-12 \mathrm{mV}$. $\mathrm{TiO}_{2} \mathrm{NPs}$ were endotoxin-free and pure, containing only oxygen and titanium [55]. Before use, $\mathrm{TiO}_{2} \mathrm{NPs}$ were suspended at $1 \mathrm{mg} / \mathrm{mL}$, in a HEPES phosphate buffer solution (HPBS: $4.4 \mathrm{mM} \mathrm{KCl}, 150 \mathrm{mM} \mathrm{NaCl}$, 12.2 mM glucose, 10.9 mM HEPES, pH 7.4) and were vortexed a high speed for $2 \mathrm{~min}$ [54]. In previous 
studies, $\mathrm{TiO}_{2} \mathrm{NPs}$ induced different toxic effects in a range from 1 to $100 \mu \mathrm{g} / \mathrm{cm}^{2}$. We also found that $40 \mu \mathrm{g} / \mathrm{cm}^{2} \mathrm{TiO}_{2} \mathrm{NPs}$ induced a strong cytotoxicity in other cells; therefore, in this work we tested concentrations equal or below this value $\left(1,5,10,20,40 \mu \mathrm{g} / \mathrm{cm}^{2}\right.$, equivalent to $5,25,50,100$ and $200 \mu \mathrm{g} / \mathrm{mL}$ ). Concentrations are presented as $\mu \mathrm{g} / \mathrm{cm}^{2}$ since $\mathrm{TiO}_{2} \mathrm{NPs}$ suspensions are unstable and precipitate.

\subsection{Internalization of $\mathrm{TiO}_{2} \mathrm{NPS}$}

Cellular uptake of nanoparticles was evaluated by TEM as previously described by Huerta-García and collaborators [55]. Cells $\left(200 \times 10^{3} /\right.$ well $)$ were treated with $5 \mu \mathrm{g} / \mathrm{cm}^{2} \mathrm{TiO}_{2} \mathrm{NPs}$ for $24 \mathrm{~h}$. Then cells were fixed with $2.5 \%$ glutaraldehyde-formaldehyde in HPBS for $1 \mathrm{~h}$. A second fixation was performed in $2 \% \mathrm{OsO}_{4}$ (1:1 in HPBS) for $1 \mathrm{~h}$. Cells were gradually dehydrated with increasing ethanol concentrations and embedded in epoxy resin (Epon 812, Sigma-Aldrich, St. Louis, MO, USA). Ultrathin sections were stained with lead citrate and alcoholic uranyl acetate. Finally, cells were examined with a transmission electron microscope (JEOL 10/10, MA, USA).

\subsection{Proliferation Assay}

$\mathrm{H} 9 \mathrm{c} 2$ cells $\left(8 \times 10^{3}\right.$ cells / well) were exposed to different concentrations of $\mathrm{TiO}_{2} \mathrm{NPs}(5,10,20$, $40 \mu \mathrm{g} / \mathrm{cm}^{2}$ ) and cell proliferation was evaluated by crystal violet staining after $72 \mathrm{~h}$ of treatment according to Márquez-Ramírez and collaborators [56].

\subsection{Cell Viability}

The reduction of 3-(4,5-dimethylthiazol-2-yl)-2,5-diphenyltetrazolium bromide (MTT) to water-insoluble formazan was used to evaluate cell viability. H9c2 cells $\left(8 \times 10^{3}\right.$ cells/well) were exposed to different concentrations of $\mathrm{TiO}_{2} \mathrm{NPs}\left(5,10,20,40 \mu \mathrm{g} / \mathrm{cm}^{2}\right)$ for $72 \mathrm{~h}$. After treatment, cells were incubated with $5 \mathrm{mg} / \mathrm{mL}$ MTT for $4 \mathrm{~h}$ and optical density at $570 \mathrm{~nm}$ was measured in a microplate spectrophotometer.

\subsection{Oxidative Stress}

The cellular redox state and oxidative stress were measured by oxidation of the $\mathrm{H}_{2}$ DCFDA (non-fluorescent) to $2^{\prime}, 7^{\prime}$-dichlorofluorescein (DCF) (highly fluorescent). Changes in the $\Delta \Psi \mathrm{m}$ were assessed as described by Huerta-García and collaborators [57] using rhodamine 123 (Rh123), a cell-permeant cationic compound captured by the active mitochondria. H9c2 cells $\left(1 \times 10^{6}\right.$ cells/treatment) were exposed to $20 \mu \mathrm{g} / \mathrm{cm}^{2} \mathrm{TiO}_{2} \mathrm{NPs}$ for 24,48 and $72 \mathrm{~h}$. After treatment, cell suspensions were incubated with $10 \mu \mathrm{M} \mathrm{H}_{2}$ DCFDA or $0.2 \mu \mathrm{g} / \mathrm{mL}$ Rh123 for $30 \mathrm{~min}$ in the dark. Finally, cells were analyzed in a flow cytometer (Fascalibur, Becton Dickinson, Franklin Lakes, NJ, USA).

\subsection{Cell Cycle Phases}

Flow cytometry and staining with PI was performed to study cell cycle changes induced by $\mathrm{TiO}_{2}$ NPs. We selected the optimal concentration of $\mathrm{TiO}_{2} \mathrm{NPs}$ for a significant reduction in cell proliferation. Therefore, $\mathrm{H} 9 \mathrm{c} 2$ cells were exposed to $20 \mu \mathrm{g} / \mathrm{cm}^{2} \mathrm{TiO}_{2} \mathrm{NPs}$ for 24,48 and $72 \mathrm{~h}$. Then cells were fixed with $70 \%$ ethanol, washed with HPBS and incubated with RNAse $(50 \mathrm{U} / \mathrm{mL})$ for $1 \mathrm{~h}$ at $37^{\circ} \mathrm{C}$. Finally, cells were stained with PI $(200 \mu \mathrm{g} / \mathrm{mL})$ and analyzed by flow cytometry.

\subsection{Cell Death}

Apoptotic and necrotic death were measured by Annexin-V/PI staining and analyzed by flow cytometry. Necrosis was also assessed by lactate dehydrogenase (LDH) release. H9c2 cells were cultured with $20 \mu \mathrm{g} / \mathrm{cm}^{2} \mathrm{TiO}_{2} \mathrm{NPs}$ for 24,48 and $72 \mathrm{~h}$, incubated with $100 \mu \mathrm{L}$ of Annexin-V plus PI in the dark at $37^{\circ} \mathrm{C}$ for $30 \mathrm{~min}$ and then examined in a flow cytometer. To evaluate LDH release, cells were cultured in phenol red-free DMEM medium and exposed to nanoparticles. After exposure, $50 \mu \mathrm{L}$ 
of the supernatant were mixed with $50 \mu \mathrm{L}$ of the substrate mix and incubated in the dark at room temperature for $30 \mathrm{~min}$. After incubation, $50 \mu \mathrm{L}$ of stop solution were added and optical density was measured at $490 \mathrm{~nm}\left(\mathrm{OD}_{490}\right)$. Data were normalized by subtracting average background of culture medium from experimental values. Percentage of cytotoxicity was calculated by the formula:

$$
\begin{gathered}
\text { Cytotoxicity }(\%)=\left(\text { Experimental LDH release }\left(\mathrm{OD}_{490}\right)\right) / \\
\left(\text { Maximum LDH release control }\left(\mathrm{OD}_{490}\right)\right) \times 100
\end{gathered}
$$

\subsection{Autophagy}

Autophagy was evaluated with a detection kit according to the manufacturer's instructions. Autophagic vesicles are detected with a $488 \mathrm{~nm}$-excitable green fluorescent dye and co-localization with LC3, a specific autophagosome marker. Cells were exposed to $20 \mu \mathrm{g} / \mathrm{cm}^{2} \mathrm{TiO}_{2}$ NPs for $24 \mathrm{~h}$. After exposure, cells were trypsinized, centrifuged at $1000 \mathrm{rpm}$ for $5 \mathrm{~min}$, and washed with $1 \times$ assay buffer. Then cells were centrifuged and re-suspended in $250 \mu \mathrm{L}$ of phenol red-free cell culture medium containing 5\% FBS and incubated with $250 \mu \mathrm{L}$ of diluted green stain solution for $30 \mathrm{~min}$ at room temperature in the dark. After incubation, cells were collected by centrifugation, washed with $1 \times$ assay buffer and analyzed in a flow cytometer. To analyze autophagy by confocal microscopy, cells were grown on coverslips. After treatment with $\mathrm{TiO}_{2} \mathrm{NPs}$, medium was removed and cells were washed twice with $1 \times$ assay buffer. Then, cells were covered with $100 \mu \mathrm{L}$ of microscopy dual detection reagent and incubated at $37^{\circ} \mathrm{C}$ for $30 \mathrm{~min}$ in the dark. Then, cells were washed with $100 \mu \mathrm{L}$ of $1 \times$ assay buffer, fixed with $4 \%$ formaldehyde and washed again three times. Finally, stained cells were analyzed with a model LSM 700 confocal microscope (Zeiss, Thornwood, NY, USA).

\subsection{Statistical Analysis}

Data are presented as mean \pm standard deviation (SD) of at least three independent experiments. Data were analyzed by one-way analysis of variance (ANOVA) followed by post-hoc Tukey's multiple comparison test, using GraphPad prism software version 5.01 (GraphPad Software La Jolla, CA, USA). Differences among groups were considered statistically significant at $p<0.05$.

Author Contributions: Conceptualization, R.L.M. and E.H.G.; Methodology and Investigation, E.H.G., I.Z.Q., H.S.B. and Z.C.V.; Software, E.H.G. and Z.C.V.; Validation and Formal Analysis, M.P.R.G.; Resources, and Data Curation, R.L.M.; Writing-Original Draft Preparation, R.L.M.; Writing-Review \& Editing, R.L.M. and E.A.M.; Visualization, R.L.M.; Supervision, E.A.M.; Project Administration, R.L.M.; Funding Acquisition, R.L.M.

Funding: This work was supported by CONACyT under grant number 182341.

Acknowledgments: We would like to thank Felipe Massó Rojas for his support with the confocal microscope and Giovanny Soca-Chafre for style and grammar corrections.

Conflicts of Interest: The authors declare no conflicts of interest.

\section{References}

1. Ranjan, S.; Dasgupta, N.; Srivastava, P.; Ramalingam, C. A spectroscopic study on interaction between bovine serum albumin and titanium dioxide nanoparticle synthesized from microwave-assisted hybrid chemical approach. J. Photochem. Photobiol. B 2016, 161, 472-481. [CrossRef] [PubMed]

2. Shakeel, M.; Jabeen, F.; Shabbir, S.; Asghar, M.S.; Khan, M.S.; Chaudhry, A.S. Toxicity of nano-titanium dioxide $\left(\mathrm{TiO}_{2}-\mathrm{NP}\right)$ through various routes of exposure: A review. Biol. Trace Elem. Res. 2016, 172, 1-36. [CrossRef] [PubMed]

3. Husain, M.; Saber, A.T.; Guo, C.; Jacobsen, N.R.; Jensen, K.A.; Yauk, C.L.; Williams, A.; Vogel, U.; Wallin, H.; Halappanavar, S. Pulmonary instillation of low doses of titanium dioxide nanoparticles in mice leads to particle retention and gene expression changes in the absence of inflammation. Toxicol. Appl. Pharmacol. 2013, 269, 250-262. [CrossRef] [PubMed] 
4. Husain, M.; Wu, D.; Saber, A.T.; Decan, N.; Jacobsen, N.R.; Williams, A.; Yauk, C.L.; Wallin, H.; Vogel, U.; Halappanavar, S. Intratracheally instilled titanium dioxide nanoparticles translocate to heart and liver and activate complement cascade in the heart of C57BL/6 mice. Nanotoxicology 2015, 9, 1013-1022. [CrossRef] [PubMed]

5. Geraets, L.; Oomen, A.G.; Krystek, P.; Jacobsen, N.R.; Wallin, H.; Laurentie, M.; Verharen, H.W.; Brandon, E.F.; de Jong, W.H. Tissue distribution and elimination after oral and intravenous administration of different titanium dioxide nanoparticles in rats. Part. Fibre Toxicol. 2014, 11. [CrossRef] [PubMed]

6. Liu, H.; Ma, L.; Zhao, J.; Liu, J.; Yan, J.; Ruan, J.; Hong, F. Biochemical toxicity of nano-anatase $\mathrm{TiO}_{2}$ particles in mice. Biol. Trace Elem. Res. 2009, 129, 70-80, Erratum in. Biol. Trace Elem. Res. 2009, 129, 170-180. [CrossRef] [PubMed]

7. Chen, Z.; Wang, Y.; Zhuo, L.; Chen, S.; Zhao, L.; Luan, X.; Wang, H.; Jia, G. Effect of titanium dioxide nanoparticles on the cardiovascular system after oral administration. Toxicol. Lett. 2015, 239, 123-130. [CrossRef] [PubMed]

8. Hong, F.; Wu, N.; Zhao, X.; Tian, Y.; Zhou, Y.; Chen, T.; Zhai, Y.; Ji, L. Titanium dioxide nanoparticle-induced dysfunction of cardiac hemodynamics is involved in cardiac inflammation in mice. J. Biomed. Mater. Res. Part A 2016, 104, 2917-2927. [CrossRef] [PubMed]

9. Sheng, L.; Wang, X.; Sang, X.; Ze, Y.; Zhao, X.; Liu, D.; Gui, S.; Sun, Q.; Cheng, J.; Cheng, Z.; et al. Cardiac oxidative damage in mice following exposure to nanoparticulate titanium dioxide. J. Biomed. Mater. Res. Part A 2013, 101, 3238-3246. [CrossRef] [PubMed]

10. Hanot-Roy, M.; Tubeuf, E.; Guilbert, A.; Bado-Nilles, A.; Vigneron, P.; Trouiller, B.; Braun, A.; Lacroix, G. Oxidative stress pathways involved in cytotoxicity and genotoxicity of titanium dioxide $\left(\mathrm{TiO}_{2}\right)$ nanoparticles on cells constitutive of alveolo-capillary barrier in vitro. Toxicol. In Vitro 2016, 33, 125-135. [CrossRef] [PubMed]

11. Zhang, X.; Li, W.; Yang, Z. Toxicology of nanosized titanium dioxide: An update. Arch. Toxicol. 2015, 89, 2207-2217. [CrossRef] [PubMed]

12. Bai, W.; Chen, Y.; Gao, A. Cross talk between poly(ADP-ribose) polymerase 1 methylation andoxidative stress involved in the toxic effect of anatase titanium dioxide nanoparticles. Int. J. Nanomed. 2015, 10, 5561-5569.

13. Rihane, N.; Nury, T.; M'rad, I.; El Mir, L.; Sakly, M.; Amara, S.; Lizard, G. Microglial cells (BV-2) internalize titanium dioxide $\left(\mathrm{TiO}_{2}\right)$ nanoparticles: Toxicity and cellular responses. Environ. Sci. Pollut. Res. Int. 2016, 23, 9690-9699. [CrossRef] [PubMed]

14. Wilson, C.L.; Natarajan, V.; Hayward, S.L.; Khalimonchuk, O.; Kidambi, S. Mitochondrial dysfunction and loss of glutamate uptake in primary astrocytes exposed to titanium dioxide nanoparticles. Nanoscale 2015, 7, 18477-18488. [CrossRef] [PubMed]

15. Periasamy, V.S.; Athinarayanan, J.; Al-Hadi, A.M.; Juhaimi, F.A.; Mahmoud, M.H.; Alshatwi, A.A. Identification of titanium dioxide nanoparticles in food products: Induce intracellular oxidative stress mediated by TNF and CYP1A genes in human lung fibroblast cells. Environ. Toxicol. Pharmacol. 2015, 39, 176-186. [CrossRef] [PubMed]

16. Glick, D.; Barth, S.; Macleod, K.F. Autophagy: Cellular and molecular mechanisms. J. Pathol. 2010, $221,3-12$. [CrossRef] [PubMed]

17. Wang, Y.; Cui, H.; Zhou, J.; Li, F.; Wang, J.; Chen, M.; Liu, Q. Cytotoxicity, DNA damage, and apoptosis induced by titanium dioxide nanoparticles in human non-small cell lung cancer A549 cells. Environ. Sci. Pollut. Res. Int. 2015, 22, 5519-5530. [CrossRef] [PubMed]

18. Armand, L.; Biola-Clier, M.; Bobyk, L.; Collin-Faure, V.; Diemer, H.; Strub, J.M.; Cianferani, S.; Dorsselaer Van, A.; Herlin-Boime, N.; Rabilloud, T.; et al. Molecular responses of alveolar epithelial A549 cells to chronic exposure to titanium dioxide nanoparticles: A proteomic view. J. Proteom. 2016, 134, 63-73. [CrossRef] [PubMed]

19. Acar, M.S.; Bulut, Z.B.; Ateş, A.; Nami, B.; Koçak, N.; Yıldız, B. Titanium dioxide nanoparticles induce cytotoxicity and reduce mitotic index in human amniotic fluid-derived cells. Hum. Exp. Toxicol. 2015, 34, 74-82. [CrossRef] [PubMed]

20. Hou, Y.; Cai, K.; Li, J.; Chen, X.; Lai, M.; Hu, Y.; Luo, Z.; Ding, X.; Xu, D. Effects of titanium nanoparticles on adhesion, migration, proliferation, and differentiation of mesenchymal stem cells. Int. J. Nanomed. 2013, 8, 3619-3630. 
21. Wang, J.; Ma, J.; Dong, L.; Hou, Y.; Jia, X.; Niu, X.; Fan, Y. Effect of anatase $\mathrm{TiO}_{2}$ nanoparticles on the growth of RSC-364 rat synovial cell. J. Nanosci. Nanotechnol. 2013, 13, 3874-3879. [CrossRef] [PubMed]

22. Takaki, K.; Higuchi, Y.; Hashii, M.; Ogino, C.; Shimizu, N. Induction of apoptosis associated with chromosomal DNA fragmentation and caspase-3 activation in leukemia $\mathrm{L} 1210$ cells by $\mathrm{TiO}_{2}$ nanoparticles. J. Biosci. Bioeng. 2014, 117, 129-133. [CrossRef] [PubMed]

23. Shi, H.; Magaye, R.; Castranova, V.; Zhao, J. Titanium dioxide nanoparticles: A review of current toxicological data. Part. Fibre Toxicol. 2013, 10, 15. [CrossRef] [PubMed]

24. Kreyling, W.G.; Hirn, S.; Möller, W.; Schleh, C.; Wenk, A.; Celik, G.; Lipka, J.; Schäffler, M.; Haberl, N.; Johnston, B.D.; et al. Air-blood barrier translocation of tracheally instilled gold nanoparticles inversely depends on particle size. ACS Nano 2014, 8, 222-233. [CrossRef] [PubMed]

25. Alfaro-Moreno, E.; García-Cuellar, C.M.; De Vizcaya Ruiz, A.; Rojas-Bracho, L.; Osornio-Vargas, A. The cellular mechanisms behind particulate matter air pollution related health effects. In Air Pollution: Health E Environmental Impacts; Gurjar, B.R., Molina, L.T., Ojha, C.S.P., Eds.; Taylor \& Francis: Abingdon, Oxford, UK, 2010; pp. 249-274.

26. Kreyling, W.G.; Holzwarth, U.; Schleh, C.; Kozempel, J.; Wenk, A.; Haberl, N.; Hirn, S.; Schäffler, M.; Lipka, J.; Semmler-Behnke, M.; et al. Quantitative biokinetics of titanium dioxide nanoparticles after oral application in rats: Part 2. Nanotoxicology 2017, 11, 443-453. [CrossRef] [PubMed]

27. Vales, G.; Rubio, L.; Marcos, R. Long-term exposures to low doses of titanium dioxide nanoparticles induce cell transformation, but not genotoxic damage in BEAS-2B cells. Nanotoxicology 2015, 9, 568-578. [CrossRef] [PubMed]

28. Wang, Y.; Wu, Q.; Sui, K.; Chen, X.X.; Fang, J.; Hu, X.; Wu, M.; Liu, Y. A quantitative study of exocytosis of titanium dioxide nanoparticles from neural stem cells. Nanoscale 2013, 7, 4737-4743. [CrossRef] [PubMed]

29. Walczyk, D.; Bombelli, F.B.; Monopoli, M.P.; Lynch, I.; Dawson, K.A.J. What the cell "sees" in bionanoscience. J. Am. Chem. Soc. 2010, 132, 5761-5768. [CrossRef] [PubMed]

30. Warheit, D.B.; Hoke, R.A.; Finlay, C.; Donner, E.M.; Reed, K.L.; Sayes, C.M. Development of a base set of toxicity tests using ultrafine $\mathrm{TiO}_{2}$ particles as a component of nanoparticle risk management. Toxicol. Lett. 2007, 171, 99-110. [CrossRef] [PubMed]

31. Prapainop, K.; Witter, D.P.; Wentworth, P. A chemical approach for cell-specific targeting of nanomaterials: Small-molecule-initiated misfolding of nanoparticle corona proteins. J. Am. Chem. Soc. 2012, 134, 4100-4103. [CrossRef] [PubMed]

32. Allouni, Z.E.; Cimpan, M.R.; Høl, P.J.; Skodvin, T.; Gjerdet, N.R. Agglomeration and sedimentation of $\mathrm{TiO}_{2}$ nanoparticles in cell culture medium. Colloids Surf. B Biointerfaces 2009, 68, 83-87. [CrossRef] [PubMed]

33. Jayaram, D.T.; Runa, S.; Kemp, M.L.; Payne, C.K. Nanoparticle-induced oxidation of corona proteins initiates an oxidative stress response in cells. Nanoscale 2017, 9, 7595-7601. [CrossRef] [PubMed]

34. Nicolas, J.; Jaafar, M.; Sepetdjian, E.; Saad, W.; Sioutas, C.; Shihadeh, A.; Saliba, N.A. Redox activity and chemical interactions of metal oxide nano- and micro-particles with dithiothreitol (DTT). Environ. Sci. Process Impacts 2015, 17, 1952-1958. [CrossRef] [PubMed]

35. El-Ghor, A.A.; Noshy, M.M.; Galal, A.; Mohamed, H.R. Normalization of nano-sized $\mathrm{TiO}_{2}$-induced clastogenicity, genotoxicity and mutagenicity by chlorophyllin administration in mice brain, liver, and bone marrow cells. Toxicol. Sci. 2014, 142, 21-32. [CrossRef] [PubMed]

36. Rueda-Romero, C.; Hernández-Pérez, G.; Ramos-Godínez, P.; Vázquez-López, I.; Quintana-Belmares, R.O.; Huerta-García, E.; Stepien, E.; López-Marure, R.; Montiel-Dávalos, A.; Alfaro-Moreno, E. Titanium dioxide nanoparticles induce the expression of early and late receptors for adhesion molecules on monocytes. Part. Fibre Toxicol. 2016, 13, 36. [CrossRef] [PubMed]

37. Mallik, A.; Bryan, S.; Puukila, S.; Chen, A.; Khaper, N. Efficacy of Pt-modified $\mathrm{TiO}(2)$ nanoparticles in cardiac cells. Exp. Clin. Cardiol. 2011, 6, 6-10.

38. Wang, C.H.; Wu, S.B.; Wu, Y.T.; Wei, Y.H. Oxidative stress response elicited by mitochondrial dysfunction: Implication in the pathophysiology of aging. Exp. Biol. Med. 2013, 238, 450-460. [CrossRef] [PubMed]

39. Burhans, W.C.; Heintz, N.H. The cell cycle is a redox cycle: Linking phase-specific targets to cell fate. Free Radic. Biol. Med. 2009, 47, 1282-1293. [CrossRef] [PubMed]

40. Ahamed, M.; Khan, M.A.; Akhtar, M.J.; Alhadlaq, H.A.; Alshamsan, A. Role of Zn doping in oxidative stress mediated cytotoxicity of $\mathrm{TiO}_{2}$ nanoparticles in human breast cancer MCF-7 cells. Sci. Rep. 2016, 6, 30196. [CrossRef] [PubMed] 
41. Gao, X.; Wang, Y.; Peng, S.; Yue, B.; Fan, C.; Chen, W.; Li, X. Comparative toxicities of bismuth oxybromide and titanium dioxide exposure on human skin keratinocyte cells. Chemosphere 2015, 135, 83-93. [CrossRef] [PubMed]

42. Kansara, K.; Patel, P.; Shah, D.; Shukla, R.K.; Singh, S.; Kumar, A.; Dhawan, A. TiO 2 nanoparticles induce DNA double strand breaks and cell cycle arrest in human alveolar cells. Environ. Mol. Mutagen. 2015, 56, 204-217. [CrossRef] [PubMed]

43. Ramkumar, K.M.; Manjula, C.; Gnanakumar, G.; Kanjwal, M.A.; Sekar, T.V.; Paulmurugan, R.; Rajaguru, P. Oxidative stress-mediated cytotoxicity and apoptosis induction by $\mathrm{TiO}_{2}$ nanofibers in HeLa cells. Eur. J. Pharm. Biopharm. 2012, 81, 324-333. [CrossRef] [PubMed]

44. Klionsky, D.J. The molecular machinery of autophagy: Unanswered questions. J. Cell Sci. 2005, 118, 7-18. [CrossRef] [PubMed]

45. Kim, I.; Rodriguez-Enriquez, S.; Lemasters, J.J. Selective degradation of mitochondria by mitophagy. Arch. Biochem. Biophys. 2007, 462, 245-253. [CrossRef] [PubMed]

46. Levine, B.; Yuan, J. Autophagy in cell death: An innocent convict? J. Clin. Investig. 2005, 115, $2679-2688$. [CrossRef] [PubMed]

47. Knaapen, M.W.; Davies, M.J.; De, B.M.; Haven, A.J.; Martinet, W.; Kockx, M.M. Apoptotic versus autophagic cell death in heart failure. Cardiovasc. Res. 2001, 51, 304-312. [CrossRef]

48. Shimomura, H.; Terasaki, F.; Hayashi, T.; Kitaura, Y.; Isomura, T.; Suma, H. Autophagic degeneration as a possible mechanism of myocardial cell death in dilated cardiomyopathy. Jpn. Circ. J. 2001, 65, 965-968. [CrossRef] [PubMed]

49. Cao, D.J.; Gillette, T.G.; Hill, J.A. Cardiomyocyte autophagy: Remodeling, repairing and reconstructing the heart. Curr. Hypertens. Rep. 2009, 11, 406-411. [CrossRef] [PubMed]

50. Nishida, K.; Kyoi, S.; Yamaguchi, O.; Sadoshima, J.; Otsu, K. The role of autophagy in the heart. Cell Death Differ. 2009, 16, 31-38. [CrossRef] [PubMed]

51. De Meyer, G.R.; Martinet, W. Autophagy in the cardiovascular system. Biochim. Biophys. Acta 2009, 1793, 485-495. [CrossRef] [PubMed]

52. Mani, K. Programmed cell death in cardiac myocytes: Strategies to maximize post-ischemic salvage. Heart Fail. Rev. 2008, 13, 193-209. [CrossRef] [PubMed]

53. Watkins, S.J.; Borthwick, G.M.; Arthure, H.M. The H9C2 cell line and primary neonatal cardiomyocyte cells show similar hypertrophic responses in vitro. In Vitro Cell. Dev. Biol. Anim. 2011, 47, 125-131. [CrossRef] [PubMed]

54. Montiel-Dávalos, A.; Ventura-Gallegos, J.L.; Alfaro-Moreno, E.; Soria-Castro, E.; García-Latorre, E.; Cabañas-Moreno, J.G.; Ramos-Godinez, M.P.; López-Marure, R. $\mathrm{TiO}_{2}$ nanoparticles induce dysfunction and activation of human endothelial cells. Chem. Res. Toxicol. 2012, 25, 920-930. [CrossRef] [PubMed]

55. Huerta-García, E.; Márquez-Ramírez, S.G.; Ramos-Godinez, M.P.; López-Saavedra, A.; Herrera, L.A.; Parra, A.; Alfaro-Moreno, E.; Gómez, E.O.; López-Marure, R. Internalization of titanium dioxide nanoparticles by glial cells is given at short times and is mainly mediated by actin reorganization-dependent endocytosis. Neurotoxicology 2015, 51, 27-37. [CrossRef] [PubMed]

56. Márquez-Ramírez, S.G.; Delgado-Buenrostro, N.L.; Chirino, Y.I.; Iglesias, G.G.; López-Marure, R. Titanium dioxide nanoparticles inhibit proliferation and induce morphological changes and apoptosis in glial cells. Toxicology 2012, 302, 146-156. [CrossRef] [PubMed]

57. Huerta-García, E.; Pérez-Arizti, J.A.; Márquez-Ramírez, S.G.; Delgado-Buenrostro, N.L.; Chirino, Y.I.; Iglesias, G.G.; López-Marure, R. Titanium dioxide nanoparticles induce strong oxidative stress and mitochondrial damage in glial cells. Free Radic. Biol. Med. 2014, 73, 84-94. [CrossRef] [PubMed]

Sample Availability: Samples of all the compounds that we used in this work are available from the authors. 